\title{
Thin Layer Drying and Modelling of Poultry Litter Briquettes
}

\author{
Mogomotsi J. Molefe ${ }^{1} \&$ Isaac N. Simate ${ }^{1}$ \\ ${ }^{1}$ Department of Agricultural Engineering, School of Engineering, University of Zambia, Lusaka, Zambia \\ Correspondence: Mogomotsi J. Molefe, Department of Agricultural Engineering, School of Engineering, \\ University of Zambia, Lusaka, Zambia. Tel: 267-75-043-374. E-mail: mogomotsimolefe@rocketmail.com
}

Received: February 1, 2018

Accepted: February 28, $2018 \quad$ Online Published: March 25, 2019

doi:10.5539/eer.v9n1p9

URL: https://doi.org/10.5539/eer.v9n1p9

\begin{abstract}
Drying is an energy consuming process influenced by humidity, air velocity and temperature and is defined as a heat conveyance process wherein the product is heated hence removing moisture. Thin layer drying equations are used to estimate drying times of products and generalizing their drying curves. In this study, mathematical modelling and prediction of drying behavior of poultry litter briquettes (PLB) was investigated through open sun drying (OSD) and solar tunnel drying for moisture content (MC) calculations. A solar tunnel dryer (STD) having a: black painted collector unit, drying unit and black painted vertical bare flat-plate chimney was used. MC results were converted to moisture ratio and fitted into 12 different thin layer drying models, using Microsoft Office Excel, which were compared according to their coefficients of determination to estimate drying curves of PLB. The most accurate model was selected based on three statistical parameters: correlation coefficient $\left(\mathrm{R}^{2}\right)$, chi-squared $\left(\chi^{2}\right)$ and Root Mean Square Error (RMSE). Solar insolation of between 220 and $1005 \mathrm{~W} / \mathrm{m}^{2}$ resulted in air temperature of up to $64^{\circ} \mathrm{C}$ at the collector unit, up to $60^{\circ} \mathrm{C}$ at the drying unit and an ambient temperature of up to $31^{\circ} \mathrm{C}$. Exposure of PLB with an average initial MC of $61 \%$ (w.b.) to these conditions resulted in a final MC in a range of $0.2-11.2 \%$ (w.b.) in 31-55 hours. PLB was dried to similar final weight from whichever drying method although OSD took longer than STD. The Logarithmic model was found to satisfactorily describe the drying curves of PLB with $\mathrm{R}^{2}$ of 9.93E-01-9.99E-01; $\chi^{2}$ of 1.36E-11-6.50E-14; and RMSE of 2.94E-02-1.30E-02.
\end{abstract}

Keywords: poultry litter, Poultry litter briquettes, drying, thin layer drying

\section{Introduction}

Poultry litter (PL) is a product from operations of poultry production and is normally perceived as a waste. It is a mixture of manure, wasted feed, feathers and bedding material. Since poultry production is increasing at an alarming rate, the disposal of the litter becomes a challenge. Environmental pollution may be a consequence due to the indiscriminative disposal of this litter (Rogeri et al., 2016). Eradication of the aforementioned repercussion can be through the drying of litter. According to Ghaly and MacDonald, (2012) drying is the abstraction of moisture from manure to render it near equilibrium with atmospheric air. Additionally, drying slows down the biological and chemical activities and also makes manure less sticky thus easier to handle. Drying can either be through Open Sun Drying or a Solar Dryer. The practice of open sun drying of agricultural products dates back to the commencement of civilization and is mostly used in developing countries. Open sun drying is characterized by spreading the product on the floor in exposition to direct sun energy. In accord with Simate and Ahrné, (2006), sun drying has limitations for large scale production due to drawbacks such as: difficulty in controlling the drying rate, more land requirement and labour for spreading the product, insect infestation and microbial contamination. Additionally, as a mitigation measure, solar drying was suggested to address some of these drawbacks. Classification of solar dryers is through the solar energy collection method and transferring it to the product as indirect, direct and mixed-type.

Solar dryers however require vigilant design and experimentation to determine the drying time, solar radiation, and attainable air conditions (temperature, relative humidity and airspeed) for uniformity when drying so that a high quality product is obtained (Simate and Cherotich, 2017). Solar dryers can be cost effective because relatively unskilled village artisans can construct, operate and maintain the dryers at minimum cost and cheap and locally available materials can be used for the construction (Simate, 2003). The natural convection solar tunnel fruit dryer (Figure 2) used in this study was fabricated from locally available materials by Simate and Cherotich, (2017) which was used to develop an appropriate thin layer drying model for mango. Thin layer drying equations are utilized for the estimation of drying times of several products and also to generalize drying curves (Sahari and Driscoll, 2013). 
In thin layer drying model, the rate of change in material moisture content in the falling rate drying period is proportional to the instantaneous difference between material moisture content and the expected material moisture content when it comes into equilibrium with the drying air. Additionally the assumption is that the material layer is thin enough or the air velocity is high (Menges and Ertekin, 2006), therefore the temperature distribution is considered uniform throughout the drying process (Pandey et al., 2015).

The transfer of heat is through convection from air to the air-food interface and by conduction to the interior of food. Mathematical models have been proved useful in the design and analysis of these transfer processes during drying (Menges and Ertekin, 2006). Therefore, the objective of this research was to study and investigate thin layer drying characteristics of poultry litter briquettes and the mathematical models which can be used to describe its thin layer drying process.

\section{Method}

This study was carried out at the University of Zambia; Latitude $15.3^{\circ} \mathrm{S}$; Longitude $28.3^{\circ} \mathrm{E}$ with the dryer situated at a site with full exposure to sunshine. The university's Department of Agricultural Engineering workshop was used to run the experiments. Experiments were conducted in June and July (winter) for drying of Poultry Litter Briquettes (PLB) in a solar tunnel dryer (STD) and open sun drying (OSD) as a control experiment. Samples of poultry litter were obtained from the university's poultry house from chickens at 4, 5 and 6 weeks old.

\subsection{Making Briquettes}

After sampling, the collected poultry litter was hand crushed so that it could blend easily when mixed with the binder (cassava flour) and water. Cassava provides strength and combination efficiency to briquettes (Teixeira et al., 2010). The poultry litter paste was prepared by adding cassava flour and water to PL in a bucket and mixed by hands until a homogenous mixture was formed. For the poultry litter sample at week $4,800 \mathrm{~g}$ of cassava flour was added to $1800 \mathrm{~g}$ of poultry litter and mixed with $2400 \mathrm{ml}$ of water. The feed-flour ratio was $44.44 \%$. $1800 \mathrm{~g}$ of poultry litter at week 5 was mixed with $300 \mathrm{~g}$ of cassava flour and $1600 \mathrm{ml}$ of water. The feed-flour ratio of this age was $16.67 \%$.

At week $6,250 \mathrm{~g}$ of cassava flour was mixed with $1800 \mathrm{~g}$ of poultry litter and $1600 \mathrm{ml}$ of water and yielded a feedflour ratio of $13.89 \%$. A research by Altun et al.,(2004) reported a ratio of $10 \%$, by weight of biomass, for both water and flour to be used. The same ratio was used in this research but resulted in a less coherent paste. Therefore, flour and water were added until a homogenous paste which could easily be molded was formed. Cassava is categorized as an organic binder. Organic binders have good bonding performance, high crush strength and drop test strength and decompose easily at high temperatures (Zhang et al., 2018). The moisture content of PLB was determined by oven drying at $70^{\circ} \mathrm{C}$ for 5 hours. The samples were dried in an oven (Jeio Tech, Model ON-02G, accuracy $\pm 0.5 \%$ ).

\subsection{Instrumentation}

After determining the initial moisture content, the solar drying experiments were conducted in the experimental setup shown in Figure 1.

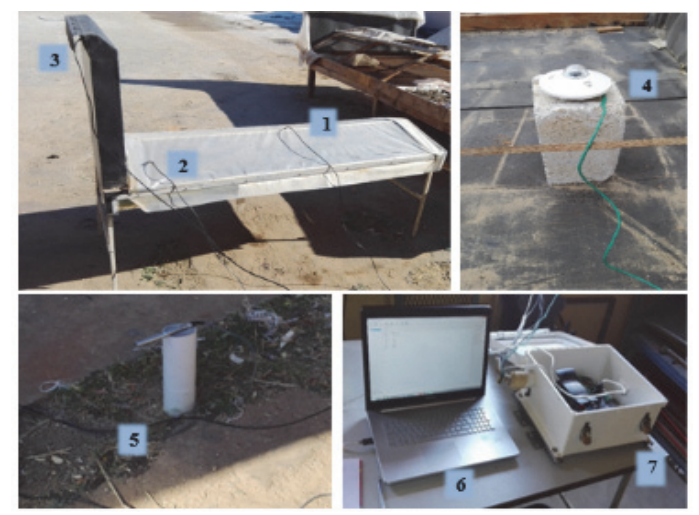

Figure 1. Experimental set-up of the solar tunnel dryer and the equipment

(1) Collector unit, (2) Drying unit, (3) Bare flat- plate chimney Unit, (4) Pyranometer (5) Humidity probe (6) Laptop and (7) Data logger.

Samples of PLB from different ages of weeks were dried using the STD which was situated in a true north position 
so that it got placed at a site with full exposure to sunshine. The dryer had 4 legs and 3 components which were the collector unit, drying unit and the chimney unit. The drying unit had an absorber plate made from Galvanized Iron sheet which was painted black to increase its solar absorptivity. The collector and drying units were covered with a transparent $200 \mu \mathrm{m}$ polythene sheet. The drying unit was made from the same material as the collector unit and was in line with the collector unit. It had a removable wire tray which served the purpose of holding the PLB during the drying period. Air exiting the drying unit was reheated in the chimney unit. The chimney unit was perpendicular to the drying unit. The STD is described in detail by (Cherotich and Simate, 2016) and (Simate and Cherotich, 2017).
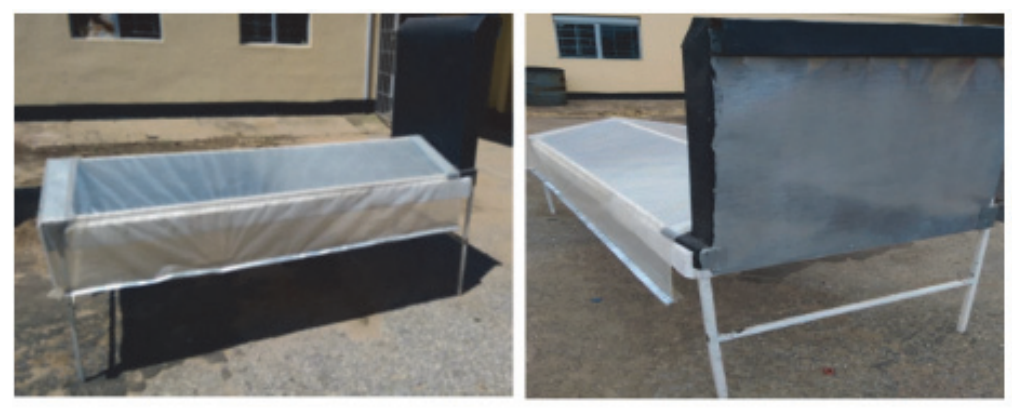

Figure 2. Side and rear views of a solar tunnel dryer

As seen from Figure 1, a multi-channel data logger (Campbell Scientific, Model CR1000) was connected to the STD to record air temperatures, relative humidity and solar radiation during the drying period. The data logger had three thermocouples (Campbell Scientific, Model T108, accuracy $\pm 0.2{ }^{\circ} \mathrm{C}$ ) for temperature measurements which were capable of recording temperatures of range -5 and $+95{ }^{\circ} \mathrm{C}$, a pyranometer (Kipp and Zonen, Model CM11, accuracy $\pm 0.5 \%$ ) placed on a horizontal flat surface near the dryer to measure solar radiation, a relative humidity probe (Model HMP60-L) placed outside the dryer to measure ambient relative humidity and the ambient temperature and was capable of temperature and humidity ranges of $-4{ }^{\circ} \mathrm{C}$ to $60{ }^{\circ} \mathrm{C}$ and 0 to $100 \%$ respectively.

The three thermocouples were used to measure air temperatures at the exit of the; collector unit ( $\left.\mathrm{T}_{\mathrm{CU}}\right)$, drying unit $\left(\mathrm{T}_{\mathrm{DU}}\right)$ and chimney unit $\left(\mathrm{T}_{\mathrm{CH}}\right)$. The relative humidity probe was used to record the ambient temperature $\left(\mathrm{T}_{\mathrm{AM}}\right)$ outside the dryer and was placed in an open area and not exposed to the sun at all times. The data logger automatically recorded readings every 10 seconds which were accessed by connecting the data logger to the laptop.

\subsection{Drying Procedure}

Drying experiments were conducted between 09:00hrs and 16:00hrs due to abundance of solar radiation. The briquettes were weighed using a digital balance (Metter, Model PE3000, accuracy $\pm 0.1 \mathrm{~g}$ ) and loaded on a wire tray on the day of the experiment. From the tray, only 3 briquettes were chosen as samples which would be used for recording the weight loss. The PLB were taken from the fore front of the tray, middle and at the far end of the tray. Each of the briquettes were marked for precision. The PLB had an average initial weight of $63 \mathrm{~g}$, length of $10 \mathrm{~cm}$ and a diameter of $25 \mathrm{~mm}$. The wire tray was loaded with 45 PLB and then put in the STD in the drying unit. By 09:00hrs all equipment was assembled and the experiment started.

The $\mathrm{T}_{\mathrm{CU}}, \mathrm{T}_{\mathrm{DU}}, \mathrm{T}_{\mathrm{CH}}, \mathrm{T}_{\mathrm{AM}}$ and the solar insolation were recorded until 16:00hrs and were downloaded to the computer. For recording weight loss of the selected PLB, weight loss was taken at an interval of 30 minutes for the first 6 hours then hourly until a fairly constant weight was achieved using the digital balance. At the end of each experimental day, the wire tray was removed from the STD and put inside the workshop. The following day, the weight loss experienced overnight was recorded and the experiment continued likewise. The PLB were loaded on the wire tray and the drying resumed. The same procedure from STD was implemented for OSD. For OSD the parameters of interest were solar insolation and ambient temperature.

\subsection{Thin Layer Drying and Modelling}

The recorded weight loss of the 3 samples of PLB at any time were averaged and used for calculating moisture content which was then converted to moisture ratio (MR) using equation 1.

$$
M R_{t}=\frac{m c_{t}(\% d \cdot b)}{m c_{0}(\% d . b)}
$$


Where; $M R_{t}$ is the moisture ratio at any time $t, m c_{t}$ is the percentage dry basis moisture content at any time $t$, and $m c_{0}$ is the percentage dry basis initial moisture content before the solar drying of samples.

The MR results were fitted into 12 thin layer models using Microsoft Excel in-built Solver in non-linear regression mode. The primary criterion for selecting the best moisture ratio equation that defines the drying curves of PLB were the correlation coefficient $\left(\mathrm{R}^{2}\right)$, the reduced chi-square $\left(\chi^{2}\right)$ and the root mean square error (RMSE). The aforementioned parameters used for selecting the drying model were calculated as follows;

$$
\begin{gathered}
R^{2}=\frac{\sum_{i=1}^{N}\left(M R_{i, \text { exp }}-M R_{i, \text { exp.mean }}\right)^{2}-\sum_{i=1}^{N}\left(M R_{i, \text { pre }}-M R_{i, \text { exp }}\right)^{2}}{\sum_{i=1}^{N}\left(M R_{i, \text { exp }}-M R_{i, \text { exp.mean }}\right)^{2}} \\
\chi^{2}=\frac{\sum_{i=1}^{N}\left(M R_{i, \text { exp }}-M R_{i, \text { pre }}\right)^{2}}{N-n} \\
R M S E=\left[\frac{1}{N} \sum_{i=1}^{N}\left(M R_{i, \text { pre }}-M R_{i, \text { exp }}\right)^{2}\right]^{\frac{1}{2}}
\end{gathered}
$$

\begin{tabular}{|c|c|c|}
\hline $\begin{array}{c}\text { Model } \\
\text { no. }\end{array}$ & Model Name & Model equation \\
\hline 1. & Newton & $M R=e^{(-k t)}$ \\
\hline 2. & Page & $M R=e^{\left(-k t^{n}\right)}$ \\
\hline 3. & Modified Page & $M R=e^{(-k t)^{n}}$ \\
\hline 4. & $\begin{array}{l}\text { Henderson and } \\
\text { Pabis }\end{array}$ & $M R=a e^{(-k t)}$ \\
\hline 5. & Logarithmic & $M R=a e^{(-k t)}+c$ \\
\hline 6. & Two term & $M R=a e^{\left(-k_{0} t\right)}+b e^{\left(-k_{1} t\right)}$ \\
\hline 7. & $\begin{array}{l}\text { Approximation of } \\
\text { Diffusion }\end{array}$ & $M R=a e^{(-k t)}+(1-a) e^{(-k b t)}$ \\
\hline 8. & Verma et al. & $M R=a e^{(-k t)}+(1-a) e^{(-g t)}$ \\
\hline 9. & $\begin{array}{l}\text { Modified } \\
\text { Henderson and } \\
\text { Pabis }\end{array}$ & $M R=a e^{(-k t)}+b e^{(-g t)}+c e^{(-h t)}$ \\
\hline 10. & $\begin{array}{l}\text { Two term } \\
\text { exponential }\end{array}$ & $\left.M R=a e^{(-k t)}+(1-a) e^{(-k a t)}\right)$ \\
\hline 11. & Wang and Singh & $M R=1+a t+b t^{2}$ \\
\hline 12. & Midilli-kucuk & $M R=a e^{\left(-k t^{n}\right)}+b t$ \\
\hline
\end{tabular}

Table 1. Thin Layer Drying Models

\section{Results and Discussions}

A total of 6 drying experiments were conducted for briquettes with an average initial moisture content of $61 \%$ (wb), which falls in the moisture content range of 50-85\% for agricultural biomass as reported by Malatji et al., (2011). Each week comprised of two drying experiments of solar tunnel drying and open sun drying which were run concurrently. The drying time ranged from 31 hours to 55 hours to reach a final moisture in a range of $0.2 \%$ to $11.2 \%(\mathrm{wb})$. Open sun drying took more time across all weeks as compared to solar tunnel drying, shown in Figure 3, due to lower temperatures and higher humidity in the ambient. Cloud cover also delayed the drying process. Each experiment was run for 7 hours and then continued the subsequent day until the drying was complete. 


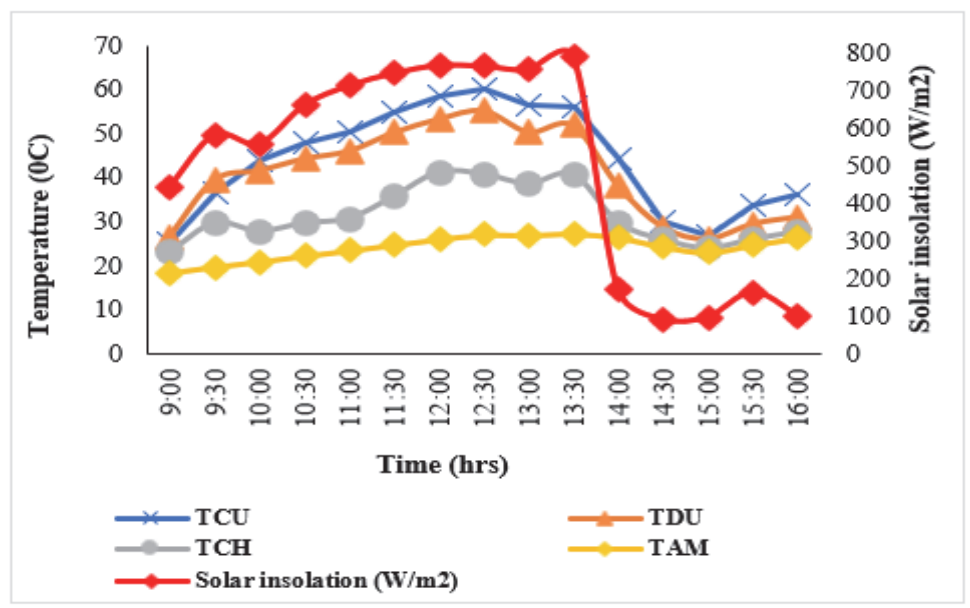

Figure 3. Air temperatures and solar radiation on a typical drying day

From Figure 3, solar insolation generally increased progressively between 9:00hrs to 13:00hrs and then subsequently decreased gradually up to 16:00hrs. Comparisons to this trend are from Daud and Simate, (2017) in the drying kinetics of sliced pineapples, Cherotich and Simate, (2016) in the drying of mango slices and Hegde et al., (2015) in the performance evaluation of solar dryer for banana where solar insolation increased from 9:00hrs to 13:00hrs and then subsequently decreased until 16:00hrs. Direct proportionality is observed between solar insolation, $\mathrm{T}_{\mathrm{AM}}, \mathrm{T}_{\mathrm{CU}}, \mathrm{T}_{\mathrm{DU}}$ and $\mathrm{T}_{\mathrm{CH}}$. That is, an increase in solar insolation generally resulted in an increase of air temperatures at different points in the dryer and the ambient. Air temperature rise and fall closely follow the insolation curve except at the end of the day. This is due to the heat storage effect caused by the polyethene cover which helped maintain air temperatures even though the insolation drastically drops (Hegde et al., 2015).

Even though solar insolation radically drops from 14:00 hours to 16:00 hours, the ambient air temperature does not drastically drop as it absorbs the heat radiated by the ground and surrounding objects. Solar insolation considerably decreased after $14: 30$ as a result of increasing cloud cover. The maximum solar insolation recorded was $790 \mathrm{~W} / \mathrm{m}^{2}$. The resulting maximum recorded $\mathrm{T}_{\mathrm{AM}}, \mathrm{T}_{\mathrm{CU}}, \mathrm{T}_{\mathrm{DU}}$ and $\mathrm{T}_{\mathrm{CH}}$ were $27^{\circ} \mathrm{C}, 60.15^{\circ} \mathrm{C}, 55.25^{\circ} \mathrm{C}$ and $41.17^{\circ} \mathrm{C}$ respectively.

Figure 4 shows moisture loss of PLB against time across weeks and drying methods. The briquettes at week 4 were dried from an initial moisture content of $59.2 \%(\mathrm{wb})$ to a final moisture content of $0.2 \%$ (wb) in a period of 31 hours in the STD whereas it took up to 38 hours in OSD to reach a final moisture content of $2.7 \%$ (wb). Elapsed drying time at week 5 was more or less similar to week 4 although the moisture loss under open sun drying was slower. At week 5 PLB was dried from an initial moisture content of $60.4 \%(\mathrm{wb})$ to a final moisture content of $4.4 \%(w b)$ in 31 hours under the STD and 10.1\% (wb) in 39 hours under OSD. At week 6 drying was slow taking more hours than other weeks. A maximum of 55 drying hours was taken due to changes in weather conditions. Initial moisture content of $62.3 \%$ (wb) was reduced to final moisture content of a range of $7.3 \%$ and $11.2 \%$ (wb) through solar tunnel drying and open sun drying respectively. Solar tunnel drying took 47 hours whereas open sun drying took 55 hours. STD was faster than OSD across all weeks. Generally, drying rates were highest during the first 9 hours of drying, when the moisture content was greatest. This applied to the drying of PLB across all weeks. Navale et al., (2015) verified that higher moisture reductions are incurred during the course of initial drying stages due to evaporation of free moisture from the outer surface layers and reduced to internal moisture migration from the inner layers to the surface. 


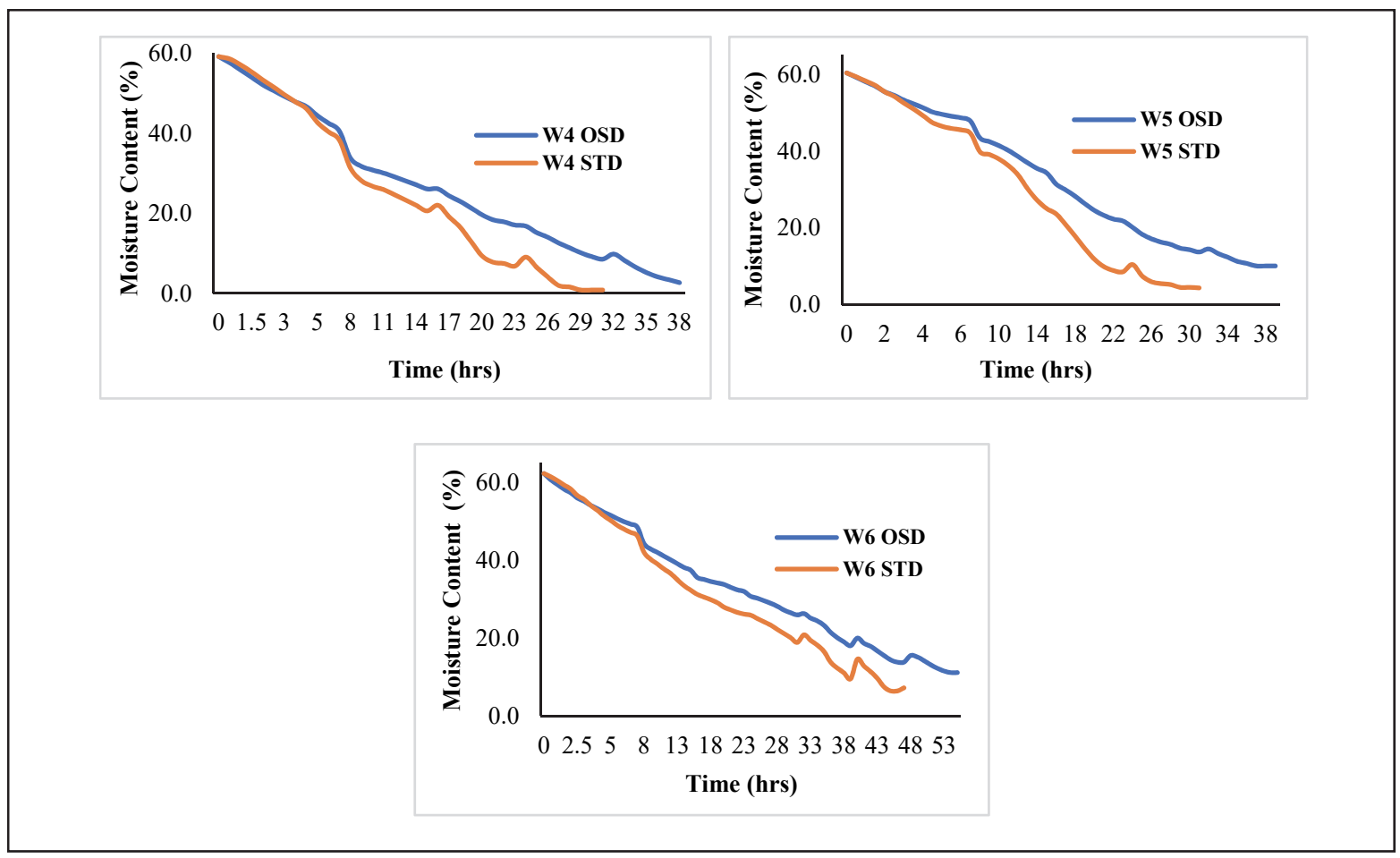

Figure 4. Moisture loss of PLB against time across weeks and drying methods W; 4, 5 and $6=$ week 4, 5 and 6

Tables 2 and 3 show all the twelve drying models with their corresponding statistical parameters used for determining the best drying model which defines the drying behavior of PLB from both STD and OSD. The order of best fit is defined by the descension of numbers, that is, 12 represents the least accurate model having Lowest R2, highest $\chi_{2}$ and RMSE while 1 represents the most accurate model having Highest R2, lowest $\chi_{2}$ and RMSE. The highlighted digits differentiate drying models appropriate to PLB at that particular week and drying method. Among all drying models, the Logarithmic model was the most consistent for all the samples of PLB either from STD or OSD except for week 4 which was from OSD which fitted best in the Two Term Exponential model. The Logarithmic model had R2 ranging from 0.993 to $0.999, \chi 2$ from $6.496 \mathrm{E}-14$ to $1.3626 \mathrm{E}-11$ and RMSE from 0.0130 to 0.0294 . The Two Term Exponential had R2 ranging from 0.996 to $0.999, \chi 2$ from 7.07E-06 to 0.0007 and RMSE from 0.0156 to 0.0357 .

Table 2. Thin layer drying modelling results for PLB (OSD) in their order

\begin{tabular}{|c|c|c|c|c|c|c|c|c|c|c|}
\hline \multirow[t]{3}{*}{ MODEL NAME } & \multicolumn{9}{|c|}{ SUN DRYING } & \multirow[b]{3}{*}{ Orde } \\
\hline & \multicolumn{3}{|c|}{ WEEK 4} & \multicolumn{3}{|c|}{ WEEK 5} & \multicolumn{3}{|c|}{ WEEK 6} & \\
\hline & Correlation & RMSE & $x^{2}$ & Correlation & RMSE & $x_{2}$ & Correlation & RMSE & $x_{2}$ & \\
\hline Page & $9.94 \mathrm{E}-01$ & $1.98 \mathrm{E}-02$ & $2.05 \mathrm{E}-06$ & $9.99 \mathrm{E}-01$ & $1.28 \mathrm{E}-02$ & $3.90 \mathrm{E}-05$ & $9.97 \mathrm{E}-01$ & $1.81 \mathrm{E}-02$ & $6.28 \mathrm{E}-05$ & 6 \\
\hline Henderson and Pabis & $9.94 \mathrm{E}-01$ & $3.04 \mathrm{E}-02$ & $9.30 \mathrm{E}-04$ & $9.99 \mathrm{E}-01$ & $1.54 \mathrm{E}-02$ & $1.02 \mathrm{E}-04$ & $9.87 \mathrm{E}-01$ & $4.22 \mathrm{E}-02$ & $2.87 \mathrm{E}-03$ & 8 \\
\hline Logarithmic & $9.94 \mathrm{E}-01$ & $3.04 \mathrm{E}-02$ & $9.30 \mathrm{E}-04$ & $9.99 \mathrm{E}-01$ & $1.42 \mathrm{E}-02$ & 3.63E-13 & $9.93 \mathrm{E}-01$ & $2.94 \mathrm{E}-02$ & $1.59 \mathrm{E}-12$ & 1 \\
\hline Two term exponential & $9.98 \mathrm{E}-01$ & $1.99 \mathrm{E}-02$ & $7.07 \mathrm{E}-06$ & $9.99 \mathrm{E}-01$ & $1.56 \mathrm{E}-02$ & $2.59 \mathrm{E}-04$ & $9.96 \mathrm{E}-01$ & $3.57 \mathrm{E}-02$ & $1.09 \mathrm{E}-06$ & 4 \\
\hline MR model (Newton) & $9.95 \mathrm{E}-01$ & $3.90 \mathrm{E}-02$ & $6.21 \mathrm{E}-05$ & $9.99 \mathrm{E}-01$ & $2.16 \mathrm{E}-02$ & 1.49E-04 & $9.91 \mathrm{E}-01$ & $6.33 \mathrm{E}-02$ & $1.62 \mathrm{E}-04$ & 9 \\
\hline MR model (Wang ve Sing) & 7.87E-01 & 3.67E-01 & $2.37 \mathrm{E}+00$ & 4.36E-01 & $1.29 \mathrm{E}+00$ & $2.87 \mathrm{E}+01$ & $2.18 \mathrm{E}-01$ & $4.92 \mathrm{E}+00$ & $5.41 \mathrm{E}+02$ & 12 \\
\hline MR model (Modified Page) & $9.95 \mathrm{E}-01$ & $3.90 \mathrm{E}-02$ & $6.36 \mathrm{E}-05$ & $9.99 \mathrm{E}-01$ & $2.16 \mathrm{E}-02$ & $1.52 \mathrm{E}-04$ & $9.91 \mathrm{E}-01$ & $6.33 \mathrm{E}-02$ & $1.65 \mathrm{E}-04$ & 8 \\
\hline MR model (Midilli-kucuk) & $9.97 \mathrm{E}-01$ & $2.02 \mathrm{E}-02$ & $1.39 \mathrm{E}-05$ & $9.99 \mathrm{E}-01$ & $1.25 \mathrm{E}-02$ & 2.49E-07 & $9.98 \mathrm{E}-01$ & $1.74 \mathrm{E}-02$ & $2.24 \mathrm{E}-06$ & 2 \\
\hline MR model (Diffusion approximation) & $9.98 \mathrm{E}-01$ & $1.86 \mathrm{E}-02$ & $3.19 \mathrm{E}-05$ & $9.99 \mathrm{E}-01$ & $1.13 \mathrm{E}-02$ & $5.85 \mathrm{E}-06$ & $9.99 \mathrm{E}-01$ & $1.36 \mathrm{E}-02$ & $1.94 \mathrm{E}-05$ & 3 \\
\hline MR model (Verma et al) & $9.95 \mathrm{E}-01$ & $2.78 \mathrm{E}-02$ & $5.46 \mathrm{E}-04$ & $9.99 \mathrm{E}-01$ & $1.39 \mathrm{E}-02$ & $5.12 \mathrm{E}-05$ & $9.89 \mathrm{E}-01$ & $3.79 \mathrm{E}-02$ & $1.93 \mathrm{E}-03$ & 10 \\
\hline MR model (Modified Henderson and Pabis) & $9.98 \mathrm{E}-01$ & $1.86 \mathrm{E}-02$ & $4.41 \mathrm{E}-05$ & $9.99 \mathrm{E}-01$ & $1.11 \mathrm{E}-02$ & $9.80 \mathrm{E}-07$ & $9.99 \mathrm{E}-01$ & $1.35 \mathrm{E}-02$ & $1.30 \mathrm{E}-05$ & 5 \\
\hline MR model (Two Term) & $9.95 \mathrm{E}-01$ & $2.78 \mathrm{E}-02$ & $5.59 \mathrm{E}-04$ & $9.99 \mathrm{E}-01$ & $1.39 \mathrm{E}-02$ & $5.43 \mathrm{E}-05$ & $9.89 \mathrm{E}-01$ & $3.79 \mathrm{E}-02$ & $1.97 \mathrm{E}-03$ & 11 \\
\hline
\end{tabular}


Table 3. Thin layer drying modelling results for PLB (STD) in their order

\begin{tabular}{|c|c|c|c|c|c|c|c|c|c|c|}
\hline \multirow[t]{3}{*}{ MODEL NAME } & & \multicolumn{9}{|c|}{ SOLAR drying } \\
\hline & \multicolumn{3}{|c|}{ WEEK 4} & \multicolumn{3}{|c|}{ WEEK 5} & \multicolumn{3}{|c|}{ WEEK 6} & \multirow[b]{2}{*}{ Order } \\
\hline & Correlation & RMSE & $\chi^{2}$ & Correlation & RMSE & $\chi^{2}$ & Correlation & RMSE & $\chi^{2}$ & \\
\hline Page & $9.96 \mathrm{E}-01$ & $2.39 \mathrm{E}-02$ & $2.55 \mathrm{E}-02$ & $9.97 \mathrm{E}-01$ & $2.40 \mathrm{E}-02$ & $4.54 \mathrm{E}-04$ & $9.96 \mathrm{E}-01$ & 2.63E-02 & $7.75 \mathrm{E}-04$ & 6 \\
\hline Henderson and Pabis & $9.97 \mathrm{E}-01$ & $2.37 \mathrm{E}-02$ & $1.46 \mathrm{E}-05$ & $9.970 \mathrm{E}-01$ & $2.46 \mathrm{E}-02$ & $5.64 \mathrm{E}-04$ & $9.89 \mathrm{E}-01$ & $4.17 \mathrm{E}-02$ & $4.56 \mathrm{E}-03$ & 8 \\
\hline Logarithmic & $9.97 \mathrm{E}-01$ & $2.36 \mathrm{E}-02$ & $3.46 \mathrm{E}-12$ & $9.98 \mathrm{E}-01$ & $2.11 \mathrm{E}-02$ & $1.36 \mathrm{E}-11$ & $9.95 \mathrm{E}-01$ & $1.30 \mathrm{E}-02$ & $6.50 \mathrm{E}-14$ & 1 \\
\hline Two term exponential & $9.97 \mathrm{E}-01$ & $2.45 \mathrm{E}-02$ & 3.08E-05 & $9.97 \mathrm{E}-01$ & $2.47 \mathrm{E}-02$ & $3.92 \mathrm{E}-04$ & $9.96 \mathrm{E}-01$ & $2.61 \mathrm{E}-02$ & $6.63 \mathrm{E}-04$ & 4 \\
\hline MR model (Newton) & $9.97 \mathrm{E}-01$ & $2.46 \mathrm{E}-02$ & $1.62 \mathrm{E}-05$ & $9.97 \mathrm{E}-01$ & 2.47E-02 & $3.81 \mathrm{E}-04$ & $9.92 \mathrm{E}-01$ & 4.79E-02 & $2.75 \mathrm{E}-03$ & 9 \\
\hline MR model (Wang ve Sing) & $7.94 \mathrm{E}-01$ & $3.57 \mathrm{E}-01$ & $1.76 \mathrm{E}+00$ & $8.34 \mathrm{E}-01$ & $3.30 \mathrm{E}-01$ & $1.71 \mathrm{E}+00$ & $2.16 \mathrm{E}-01$ & $3.87 \mathrm{E}+00$ & $2.99 \mathrm{E}+02$ & 12 \\
\hline MR model (Modified Page) & $9.97 \mathrm{E}-01$ & $2.46 \mathrm{E}-02$ & $1.67 \mathrm{E}-05$ & $9.97 \mathrm{E}-01$ & $2.47 \mathrm{E}-02$ & $3.92 \mathrm{E}-04$ & $9.92 \mathrm{E}-01$ & $4.79 \mathrm{E}-02$ & $2.81 \mathrm{E}-03$ & 8 \\
\hline MR model (Midilli-kucuk) & $9.97 \mathrm{E}-01$ & $2.30 \mathrm{E}-02$ & $2.01 \mathrm{E}-06$ & $9.98 \mathrm{E}-01$ & $2.07 \mathrm{E}-02$ & $3.51 \mathrm{E}-07$ & $9.96 \mathrm{E}-01$ & $2.33 \mathrm{E}-02$ & $1.95 \mathrm{E}-06$ & 2 \\
\hline MR model (Diffusion approximation) & $9.97 \mathrm{E}-01$ & $2.34 \mathrm{E}-02$ & $2.89 \mathrm{E}-06$ & $9.97 \mathrm{E}-01$ & $2.47 \mathrm{E}-02$ & 4.03E-04 & $9.99 \mathrm{E}-01$ & $1.90 \mathrm{E}-02$ & $8.38 \mathrm{E}-05$ & 3 \\
\hline MR model (Verma et al) & $9.97 \mathrm{E}-01$ & $2.34 \mathrm{E}-02$ & $6.08 \mathrm{E}-06$ & $9.97 \mathrm{E}-01$ & $2.45 \mathrm{E}-02$ & $5.37 \mathrm{E}-04$ & $9.90 \mathrm{E}-01$ & $4.04 \mathrm{E}-02$ & $3.60 \mathrm{E}-03$ & 10 \\
\hline MR model (Modified Henderson and Pabis) & $9.97 \mathrm{E}-01$ & $2.28 \mathrm{E}-02$ & $3.30 \mathrm{E}-04$ & $9.97 \mathrm{E}-01$ & $2.45 \mathrm{E}-02$ & $5.87 \mathrm{E}-04$ & $9.98 \mathrm{E}-01$ & $1.61 \mathrm{E}-02$ & $2.82 \mathrm{E}-05$ & 5 \\
\hline MR model (Two Term) & $9.97 \mathrm{E}-01$ & $2.36 \mathrm{E}-02$ & $6.18 \mathrm{E}-05$ & $9.97 \mathrm{E}-01$ & $2.45 \mathrm{E}-02$ & $5.53 \mathrm{E}-04$ & $9.90 \mathrm{E}-01$ & 4.04E-02 & 3.67E-03 & 11 \\
\hline
\end{tabular}

The drying behavior of PLB, which is best defined by the Logarithmic drying model, is shown in Figure 5. The model gave a considerably good fit for all the PLB samples both from STD and OSD. It can be observed that the experimental and model predicted MR compared well and this validates the Logarithmic model for this study.
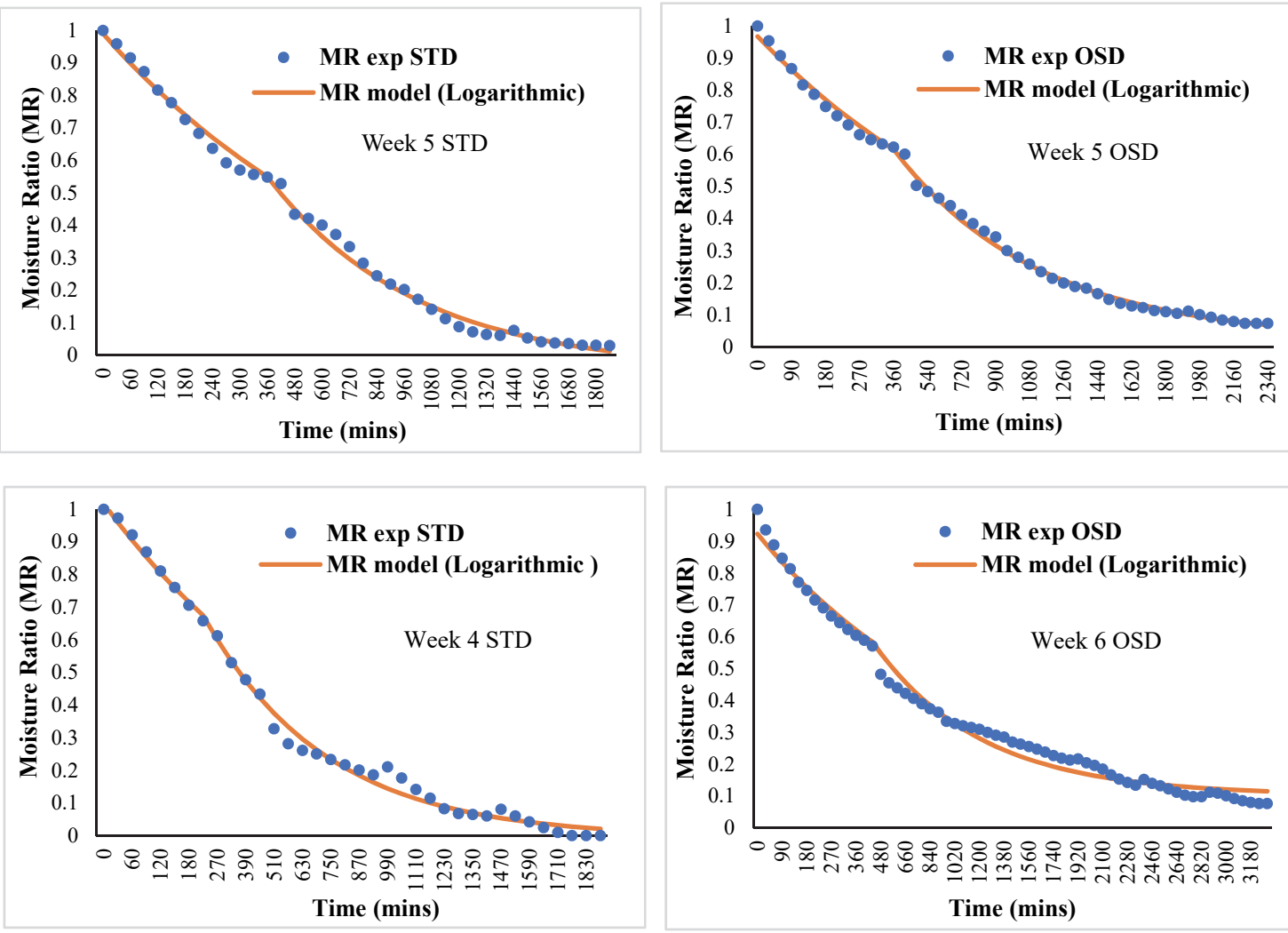

Figure 5. Variation of experimental MR and model MR against time for week 5 STD, week 5 OSD, week 4 STD and week 6 OSD respectively 


\section{Conclusion}

From all weeks, STD was faster than OSD yielding considerably higher temperatures than the ambient. The attained drying conditions from the STD are ideal for drying PLB and is both a low energy and labour consuming process mostly suitable in developing countries. Precise efficiency was achieved through the use of the STD since moisture removal from the briquettes took less time than OSD. The Logarithmic drying model is the best model for predicting the drying behaviour of PLB from both STD and OSD since it proved to be the most consistent model with values of prediction criterion; $\mathrm{R}^{2}$ of 9.93E-01-9.99E-01; $\chi^{2}$ of 1.36E-11-6.50E-14; and RMSE of 2.94E02-1.30E-02.

\section{Acknowledgement}

The authors wish to acknowledge the funding from the European Commission through the METEGA-Intra-ACP Academic Mobility Scheme for enabling the first author to embark on the MEng study as well as the supervisor, Dr. Simate for the support provided throughout the research. Thanks for the personal assistance in the preparation of this manuscript.

\section{References}

Altun, N. E., Hicyilmaz, C., \& Bagci, A. S. (2004). Influence of Coal Briquette Size on the Combustion Kinetics. Fuel Processing Technology, 85, 1345-1357. https://doi.org/10.1016/j.fuproc.2003.09.010.

Cherotich, S., \& Simate, I. N. (2016). Experimental Investigation and Mathematical Modelling of a Natural Convection Solar Tunnel Dryer', International Journal of Scientific \& Engineering Research, 7(5), 597-604. Retrieved from http://www.ijser.org.

Daud, L. E. I., \& Simate, I. N. (2017). Drying Kinetics of Sliced Pineapples in a Solar Conduction Dryer. Energy and Environment Research, 7(2), 14-26. https://doi.org/10.5539/eer.v7n2p14.

Ghaly, A. E., \& MacDonald, K. N. (2012). Drying of Poultry Manure for Use as Animal Feed. American Journal of Agricultural and Biological Science, 7(3), 239-254. https://doi.org/10.3844/ajabssp.2012.239.254.

Hegde, V. N., Viraj, Shrikanth, H., Samyukthkumar, K., Rathod, Puneet, A. H., \& K Badari, N. (2015). Design, Fabrication and Performance Evaluation of Solar Dryer for Banana. Energy, Sustainability and Society. Energy, Sustainability and Society, 5(23), 1-12. https://doi.org/10.1186/s13705-015-0052-x.

Malatji, P., Mamphweli, N. S., \& Meincken, M. (2011). The Technical Pre-Feasibility To Use Briquettes Made From Wood and Agricultural Waste For Gasification In A Downdraft Gasifier For Electricity Generation. Journal of Energy in Southern Africa, 22(4), 2-7. Retrieved from http://www.scielo.org.za/scielo.php?script=sci_arttext\&pid=S1021-447X2011000400001.

Menges, H. O., \& Ertekin, C. (2006). Mathematical modeling of thin layer drying of Golden apples. Journal of Food Engineering, 77, 119-125. https://doi.org/10.1016/j.jfoodeng.2005.06.049.

Navale, S. R., Harpale, V. M., \& Mohite, K. C. (2015). Comparative Study of Open Sun and Cabinet Solar Drying for Fenugreek Leaves. International Journal of Renewable Energy Technology Research, 4(2), 1-9. Retrieved from http://ijretr.org.

Pandey, S. K., Diwan, S., \& Soni, R. (2015). Review of Mathematical Modelling of Thin Layer Drying. International Journal of Current Engineering and Scientific Research, 2(11), 96-107. Retrieved from troindia.in/journal/ijcesr/vol2iss11/96-107.pdf.

Rogeri, D. A., Ernani, P. R., Mantovan, A., \& Lourenço, K. S. (2016). Composition of Poultry Litter in Brazil. Rev Bras Cienc Solo, 40, 1-7. https://doi.org/10.1590/18069657rbcs20140697.

Sahari, Y., \& Driscoll, R. H. (2013). Thin Layer Drying of Agricultural Products: A Review. In Noor, M. M., Rahman, M. M., \& Ismail, J. (Eds), 3rd Malaysian Postgraduate Conference (MPC2013) 4-5 July 2013, Sydney, New South Wales, Australia. Sydney, pp. 8-21. Retrieved from https://www.researchgate.net/publication/256293255.

Simate, I. N. (2003). Optrmization of Mixed-Mode and Indirect-Mode Natural Convection Solar Dryers. Renewable Energy, 28(03), 435-453. https://doi.org/10.1016/S0960-1481(02)00041-1.

Simate, I. N., \& Ahrné, L. M. (2006). Dehydration of Tropical Fruits. In Hui, Y. H. (Ed.), Handbook of Food Science, Technology, and Engineering, Volume 3. CRC Taylor \& Francis, Boca Raton., pp. 104-1-104-18.

Simate, I. N., \& Cherotich, S. (2017). Design and Testing of a Natural Convection Solar Tunnel Dryer for Mango. Journal of Solar Energy, 1-10. Retrieved from https://doi.org/10.1155/2017/4525141. 
Teixeira, S. R., Pena, A. F. V., \& Miguel, A. G. (2010). Briquetting of charcoal from sugar-cane bagasse fly ash (scbfa) as an alternative fuel. Waste Management. Elsevier Ltd, 30, 804-807. https://doi.org/10.1016/j.wasman.2010.01.018.

Zhang, G., Sun, Y., \& Xu, Y. (2018). Review of Briquette Binders and Briquetting Mechanism', Renewable and Sustainable Energy Reviews. Elsevier Ltd, 82, 477-487. https://doi.org/10.1016/j.rser.2017.09.072.

\section{Copyrights}

Copyright for this article is retained by the author(s), with first publication rights granted to the journal.

This is an open-access article distributed under the terms and conditions of the Creative Commons Attribution license (http://creativecommons.org/licenses/by/4.0/). 